Journal of Engineering Sciences, Assiut University, Vol. 36, No. 4, pp.787 -798, July 2008

\title{
LAND COVER/LAND USE CHANGE DETECTION USING LANDSAT SATELLITE IMAGES: CASE STUDY IN ADEN GOVERNORATE, REPUBLIC OF YEMEN
}

\author{
A. M. Abdlwahed'. Farrag Ali Farrag ${ }^{2}$, and \\ Magda Saeed Alnoban ${ }^{3}$ \\ ${ }^{I}$ Prof. of surveying and geodesy, Civil Eng. Dpt. Faculty of Engineering, \\ Assiut University \\ ${ }^{2}$ Prof. of surveying and photogrammetry, Civil Eng. Dpt. Faculty of \\ Engineering, Assiut University. \\ ${ }^{3}$ Staff member in Faculty of Engineering, Aden University. \\ ${ }^{2}$ farrag@aun.edu.eg \& ${ }^{3}$ magdayemen@yahoo.com
}

(Received June 1, 2008 Accepted July 1, 2008)

\begin{abstract}
Remote sensing techniques become more important for temporal information describing the extent of land resources changes over time, especially in rapidly growing of urban areas. We have developed a methodology to monitor landcover/landuse changes using multitemporal Landsat images. The purpose of this research is to detect changes in landuse/landcover using Landsat satellite images during a period from 1987 up to 2003 for Aden governorate (in Republic of Yemen). Two Landsat images were used. The first one was captured on 1987 by landsat-5 (TM) and the second one was captured on 2003 by landsat-7 $(E T M+)$. To achieve the changes in landcover/landuse different methods of change detection were used such as: Post classification comparison method, Image differencing method, Composite image method, and Normalize difference vegetation method. The objectives of the present study are to detect and map the changes in land use/landcover using multi temporal Landsat images. This study was applied on Aden governorate (Republic of Yemen), over the period 1987 up to 2003.
\end{abstract}

KEYWORDS: Change detection, image processing, classification accuracy.

\section{INTRODUCTION}

By using the remote sensing techniques it is possible to detect the specific changes in the area. Temporal analysis is a major application of remotely sensed data to detect specific changes by the use of multi date data sets to discriminate areas of Landcover/Landuse change between dates of imaging. Data from the Landsat TM, with synoptic and regular coverage offers the potential for detection and inventory of disturbance and other changes that occur in Landuse, cover type, and cover condition in areas of research interest [Aldakheel, 2005].

The change detection techniques applied in this study are post-classification comparison, image differencing, Compositing image, and Normalize difference vegetation index. 


\section{STUDY AREA}

This study is applied on governorate of Aden (Republic of Yemen). The study area is $29.8 \times 30.34 \mathrm{~km}$. Aden is located at $12^{\circ} 48^{\prime} \mathrm{N}-12^{\circ} 55^{\prime} \mathrm{N}$ and $45^{\circ} 02^{\prime} \mathrm{E}-45^{\circ} 55^{\prime} \mathrm{E}$. It consists of number of small towns: Crater, the original port city, the industrial city known as little Aden with its large oil refinery, and Madinat ash-sha'b. Two suburbs, Khormakser and Shiekh-othman, both lie north of crater, the old city, with the international airport situated in between.

\section{DATA AND METHODOLOGY}

Remote Sensing technology is an ideal tool to identify, locate and map various types of lands associated with different landform units. The timely information about the changing pattern of land use plays significant role in land use planning and sustainable land development.

One of the most widely used data format for information extraction about the Landuse/Landcover is the False Color Composite (FCC) of the image.

The research has two main steps. The first step is classification of satellite data for Landuse/Landcover (LULC) types, image analysis and accuracy estimation. The second step is concentrated on the change detection analysis in the LULC types. Analysis of satellite data includes registration, classification and change detection using post-classification comparison. Satellite data analysis is done by using ERDAS Imagine 8.7 software.

For the study area, two Landsat images with 30 meter ground resolution were used. The first image was Landsat 5 TM captured in 18 October 1987 and the second image was Landsat 7 ETM+ captured in 15 May 2003. Plate 1 and plate 2 show the false color composite (band 4 as red, band 3 as green, and band 2 as blue) of 1987 image and 2003 image respectively for the study area. In order to prepare the images for an accurate change detection comparison, it is essential to make radiometric corrections for the two images and geometrically rectify one image to another (the 1987 image is rectified to 2003 image).

\subsection{Radiometric Corrections}

Radiometric correction of satellite imagery can be divided into two broad categories, namely absolute and relative. Absolute radiometric correction converts the digital number of a pixel to percent reflectance value using established transformation equation. Relative radiometric correction normalizes multiple satellite scenes to each other [Janzen et al 2006].

Factors that commonly contribute to radiometric error include improperly calibrated or faulty detectors, atmosphere scattering and absorption, and topographic slope and aspect [Jensen, 1996]. Additionally, factors such as solar zenith angle and earth-sun distance also impact the radiance measured by sensing systems and need to be considered [Lillesand, 2000]. 


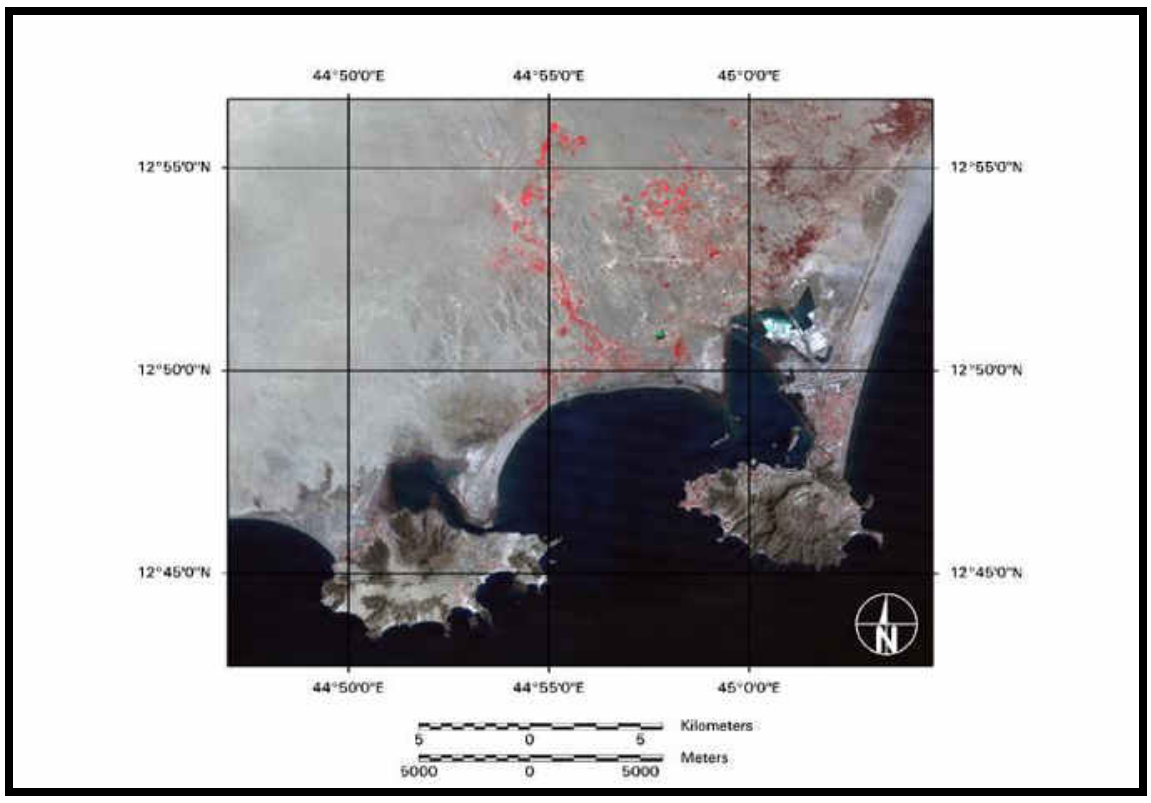

Plate 1: False color composite of 1987 image for Aden Governorate.

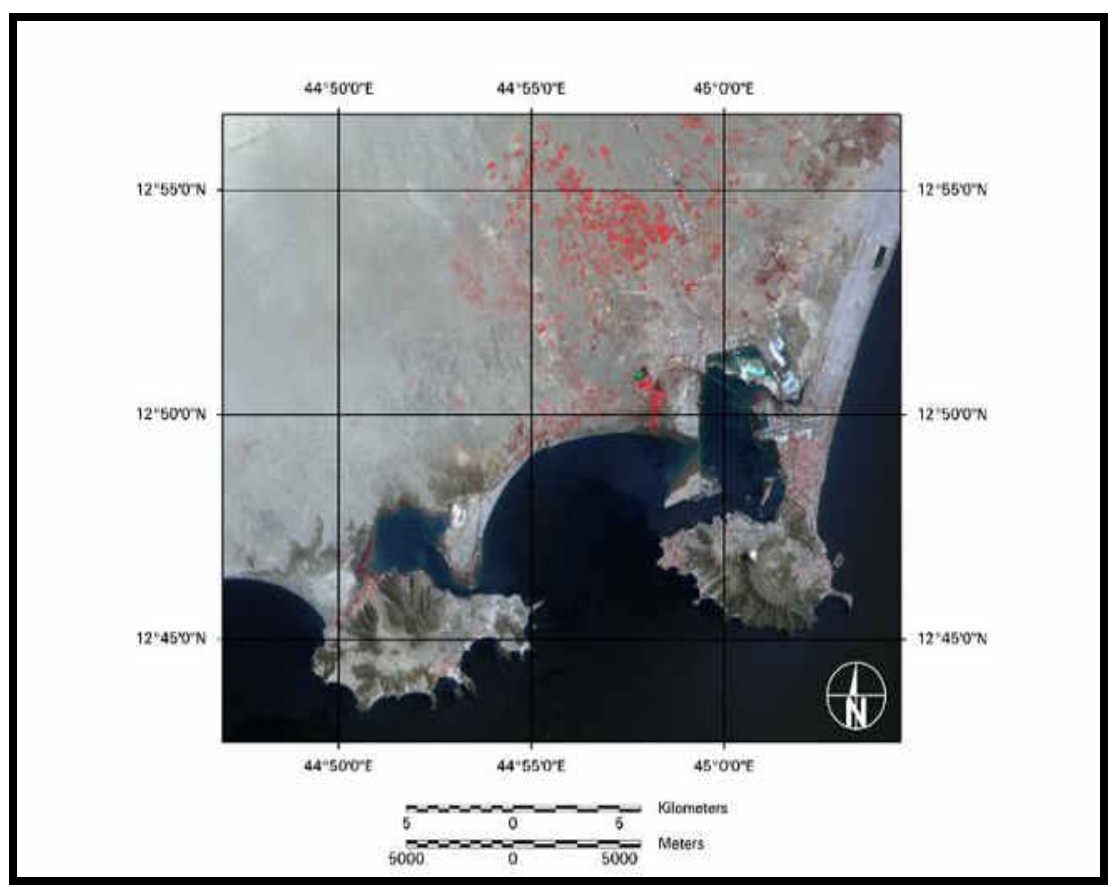

Plate 2: False color composite of 2003 image for Aden Governorate. 
Radiometric calibration was a multi-step process that involved the use of standard equations to convert 8-bit satellite-quantized calibrated digital numbers (DN) to at-satellite reflectance summarized as following [Schroeder et al, 2006]:

Landsat-5 images were first converted to at-satellite radiance using, where:

$$
\mathrm{L}_{\mathrm{sat}}=(\mathrm{DN}-\mathrm{B}) / \mathrm{G} \text {, }
$$

$\mathrm{L}_{\text {sat }}$ is band specific at-satellite radiance $\left(\mathrm{Wm}^{-2} \mathrm{sr}^{-1} \mu \mathrm{m}^{-1}\right)$.

$\mathrm{DN}$ is satellite quantized calibrated digital number.

$\mathrm{B}$ is band specific bias in DN.

$\mathrm{G}$ is band- specific gain $\left(\mathrm{m}^{2} \mathrm{sr} \mu \mathrm{m} \mathrm{W}^{-1}\right)$.

Landsat-7 images were converted to at-satellite radiance using,

$\mathrm{L}_{\mathrm{sat}}=\left(\left(\mathrm{LMAX}_{\mathrm{sat}}-\mathrm{LMIN}_{\mathrm{sat}}\right) /(\mathrm{DNMAX}-\mathrm{DNMIN})\right) *(\mathrm{DN}-\mathrm{DNMIN})+\mathrm{LMIN}_{\mathrm{sat}}$, where:

LMAX $_{\text {sat }}$ is band-specific radiance scaled to DNMAX $\left(\mathrm{Wm}^{-2} \mathrm{sr}^{-1} \mu \mathrm{m}^{-1}\right)$.

LMINsat is band-specific spectral radiance scaled to DNMIN $\left(\mathrm{Wm}^{-2} \mathrm{sr}^{-1} \mu \mathrm{m}^{-1}\right)$.

DNMAX is maximum quantized calibrated digital number (255).

DNMIN is minimum quantized calibrated digital number (1).

After conversion to at-satellite radiance, each image was converted to atsatellita reflectance (assuming a uniform Lambertain surface under cloudless conditions) using,

where:

$$
\rho_{\mathrm{ASR}}=\left(\pi \mathrm{L}_{\mathrm{sat}} \mathrm{d}^{2}\right) /(\operatorname{Ecos}(\theta)),
$$

$\mathrm{L}_{\text {sat }}$ is band specific at-satellite radiance $\left(\mathrm{Wm}^{-2} \mathrm{sr}^{-1} \mu \mathrm{m}^{-1}\right)$.

$\rho_{\text {ASR }}$ is at-satellite reflectance.

$\mathrm{E}$ is Mean solar exoatmospheric irradiances $\left(\mathrm{Wm}^{-2} \mu \mathrm{m}^{-1}\right)$.

$\theta$ is solar zenith angle.

$\mathrm{d}^{2}$ is Earth sun distance in astronomical units.

\subsection{Geometric correction}

Geometric correction is one important preprocess step used to correct image against geometric distortion that might be happened. Both images were registered to the UTM projection zone 38; by the process of image to image registration to check the quality of the geometric correction of the images. For this purpose, 22 Control Points (CP) well distributed and defined on the two images were used. Based on these points, the 1987 was registered to the 2003 image. The 1987 image was rectified. Total Root Mean Square Errors (RMSE) in check point was ( 0.25 pixels) about $7.5 \mathrm{~m}$. The process of 2003 image was carried out using the nearest neighbor method (in order to avoid any smoothing to the original image data).

\subsection{Change Detection}

Change detection involves the use of multi-temporal data sets to discriminate areas of land cover change between dates of imaging. The types of changes that might be of interest can range from short term phenomena such as snow cover or flood water to long term phenomena such as urban fringe development or desertification [Lillesand, 2000]. 
A number of change detection techniques have been developed over the last (20)years, as mentioned by, [K.C.Seto, 2004], are:

- Post Classification Comparison.

- Image Differencing.

- Normalized Vegetation Index Differencing.

- Image Compositing.

- Image Regression.

- Image Rationing.

- Principal Component Analysis.

- Change Vector Analysis.

The utilized techniques in this study are post-classification comparison, image differencing, normalize vegetation index differencing, and image compositing.

\section{Post Classification Comparison}

The post classification change detection technique is one of many change detection methods used by remote sensing scientists. The post classification comparison technique compares on a pixel by pixel basis multiple classified maps created from remotely sensed data collected at different times. This technique not only identifies areas of change, but also provides information about the direction of the observed change [Peterson, 2006].

\section{Image Differencing}

Image differencing is probably the most widely applied change detection algorithm [Singh, 1989]. It involves subtracting one date of imagery from a second date that has been precisely registered to the first. The Geo-referenced images of two different time periods (t1) and (t2) were subtracted on a band by band and pixel by pixel basis to produce an image which represents the change between the two time periods. This technique takes into account the difference of radiance values of pixels between two different dates. Differences in atmospheric condition differences in sensor calibration, moisture condition, illumination condition also affect the radiance of the pixels [Ramachandra, 2004].

\section{Normalized Differencing Vegetation Index}

The Normalized Difference Vegetation Index (NDVI), has been extensively used for vegetation monitoring, crops yield assessment, and drought detection.

The (NDVI) is calculated as:

Where:

(NIR - RED) / (NIR + RED),

NIR is the reflectance radiated in near-infrared wave band.

RED is the reflectance radiated in the visible red wave band of the satellite radiometer.

The ability to compare pixel values by this way would be useful for removing seasonal vegetation changes, facilitating interpretation through the historical record and between different vegetation cover [Peters et al, 2002].

\section{Image Compositing}

To examine the same pixel in two different images, both multispectral images combined into one image producing a new one. This process is called compositing 
since each original image has six Landsat channels excluding the thermal one, the new image will have twelve channels, six from each image.

\section{Results and Discussion}

Four main classes of change detection were obtained by using supervised classification using maximum likelihood classification; they are No Change (N-C), Sand to Vegetation (S-V), Sand/Mountain areas to Urban (S/M-U), and Shallow sea water to soil filling (Sh-F). The result of the tested techniques can be summarized as follows:

\subsection{Post Classification Comparison}

First, supervised classification was carried out on both images to classify each image separately. The resulted classified images from 1987 and 2003 used as, inputs to the processing program to create a change matrix. Eleven Landcover classes in the single image give 121 potential types of changes between the two dates. Change between dates is summarized by four main change categories: No Change (N-C), Sand/Mountain to Urban (S/M-U), Sand to Vegetation (S-V) and Shallow sea water to Soil filling (Sh-F) as shown in plate 3.

From plate 3 one can notes that, there was an increase in urban and vegetation areas over the 16-years period. The error matrix of the classified image is given in Table 1.

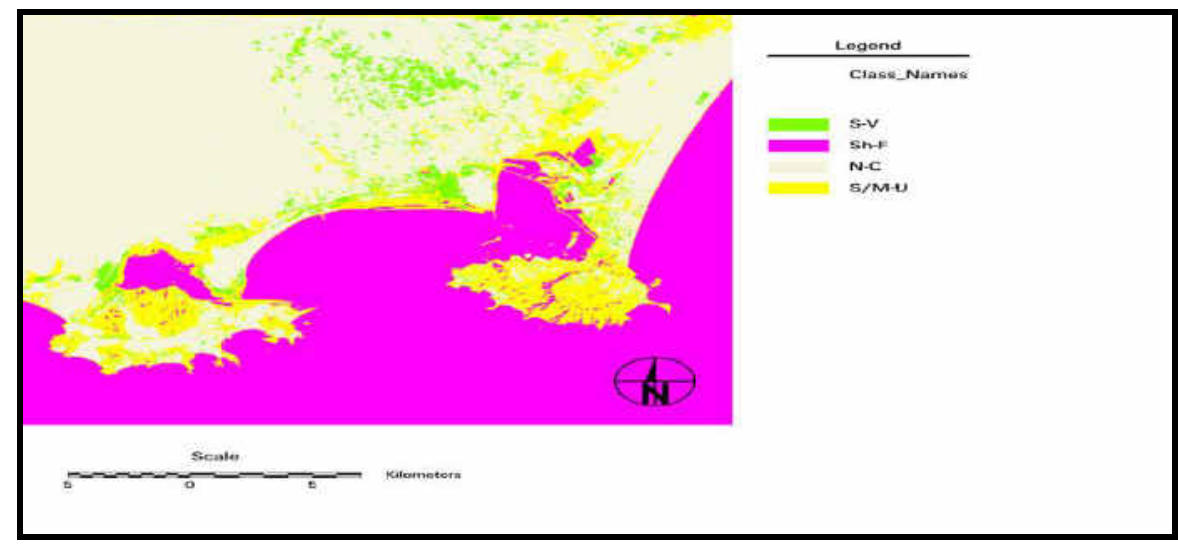

Plate 3: Post Classification Comparison of 1987 and 2003 images

Table 1: Error matrix of post comparison classification of 1987 and 2003

\begin{tabular}{|c|c|c|c|c|c|c|c|}
\hline $\begin{array}{l}\text { Class- } \\
\text { names }\end{array}$ & $\mathrm{S}-\mathrm{V}$ & Sh-F & $\mathrm{N}-\mathrm{C}$ & S/M-U & Total & $\begin{array}{c}\text { Produc } \\
\text { er } \\
\text { accurac }\end{array}$ & $\begin{array}{c}\text { Users } \\
\text { accurac } \\
\text { y }\end{array}$ \\
\hline $\mathrm{S}-\mathrm{V}$ & 52 & 0 & 0 & 4 & 56 & $100 \%$ & $92.85 \%$ \\
\hline Sh-F & 0 & 91 & 0 & 0 & 91 & $94.79 \%$ & $100 \%$ \\
\hline $\mathrm{N}-\mathrm{C}$ & 0 & 5 & 768 & 0 & 773 & $100 \%$ & $99.35 \%$ \\
\hline S/M-U & 0 & 0 & 0 & 296 & 296 & $98.66 \%$ & $100 \%$ \\
\hline Total & 52 & 96 & 768 & 300 & 1216 & & \\
\hline \multicolumn{2}{|c|}{ Kappa $=98.60 \%$} & \multicolumn{4}{|c|}{ Overall accuracy $=99.25 \%$} & & \\
\hline
\end{tabular}




\subsection{Image Differencing}

In this method 1987 image bands were subtracted from 2003 image bands, then the resulting image was classified into the same four classes. The classified image is given in plate 4 . The error matrix of band difference image is given table 2 .

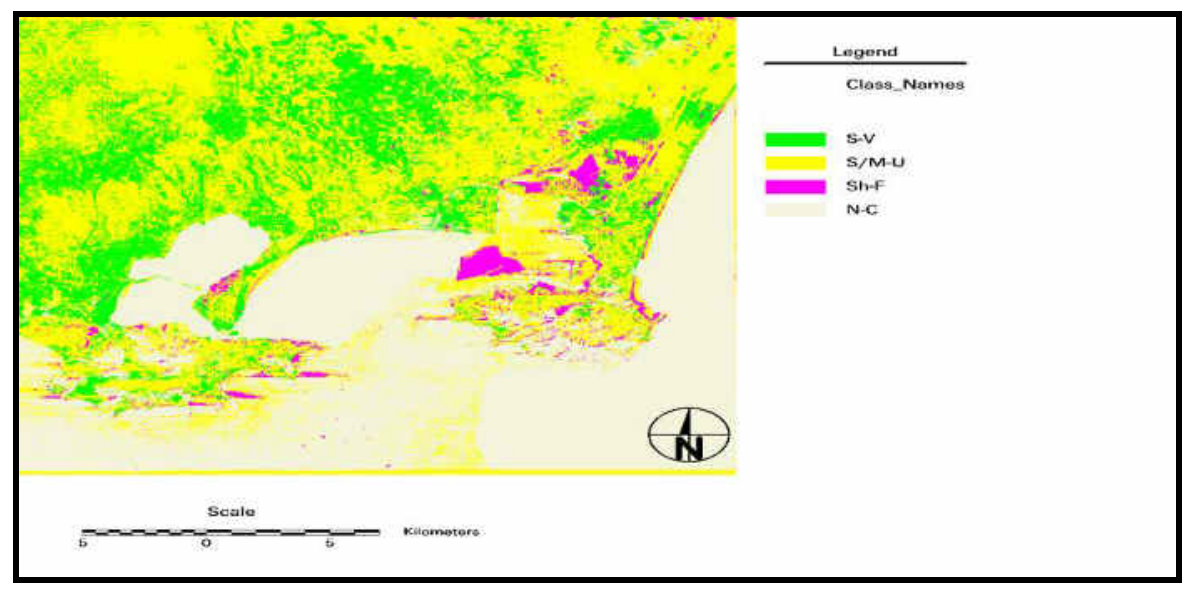

Plate 4: Classified image using image differencing technique

Table 2: Error matrix of the classified image using image differencing technique

\begin{tabular}{|c|c|c|c|c|c|c|c|}
\hline $\begin{array}{l}\text { Class- } \\
\text { names }\end{array}$ & $\mathrm{S}-\mathrm{V}$ & Sh-F & $\mathrm{N}-\mathrm{C}$ & S/M-U & Total & $\begin{array}{l}\text { Producer } \\
\text { accuracy }\end{array}$ & $\begin{array}{c}\text { Users } \\
\text { accuracy }\end{array}$ \\
\hline $\mathrm{S}-\mathrm{V}$ & 46 & 0 & 0 & 3 & 49 & $100 \%$ & $93.87 \%$ \\
\hline Sh-F & 0 & 54 & 0 & 0 & $\overline{54}$ & $100 \%$ & $100 \%$ \\
\hline $\mathrm{N}-\mathrm{C}$ & 0 & 0 & 2890 & 7 & 2897 & $99.55 \%$ & $99.75 \%$ \\
\hline S/M-U & $\overline{0}$ & 0 & 13 & 1268 & 1281 & $99.21 \%$ & $98.98 \%$ \\
\hline Total & 46 & 54 & 2903 & $\begin{array}{ll}1278 \\
\end{array}$ & 4281 & & \\
\hline \multicolumn{2}{|c|}{ Kappa $=98.81 \%$} & \multicolumn{4}{|c|}{ Overall accuracy $=99.46 \%$} & & \\
\hline
\end{tabular}

\subsection{Normalized Differencing Vegetation Index}

In this method both NDVIs for each image were found separately, then the resulting images were subtracted from each other. To determine the changes the resulting image from subtraction was classified into the same four classes. The classified image is given in plate 5 and the error matrix of band difference image is given in table 3.

\subsection{Compositing Method}

In this method both images were composite to each other to give twelve bands, six bands from each one. Then this resulting image was classified into the same four classes as shown in plate 6 , and the error matrix of classified compositing image is given in Table 4. 


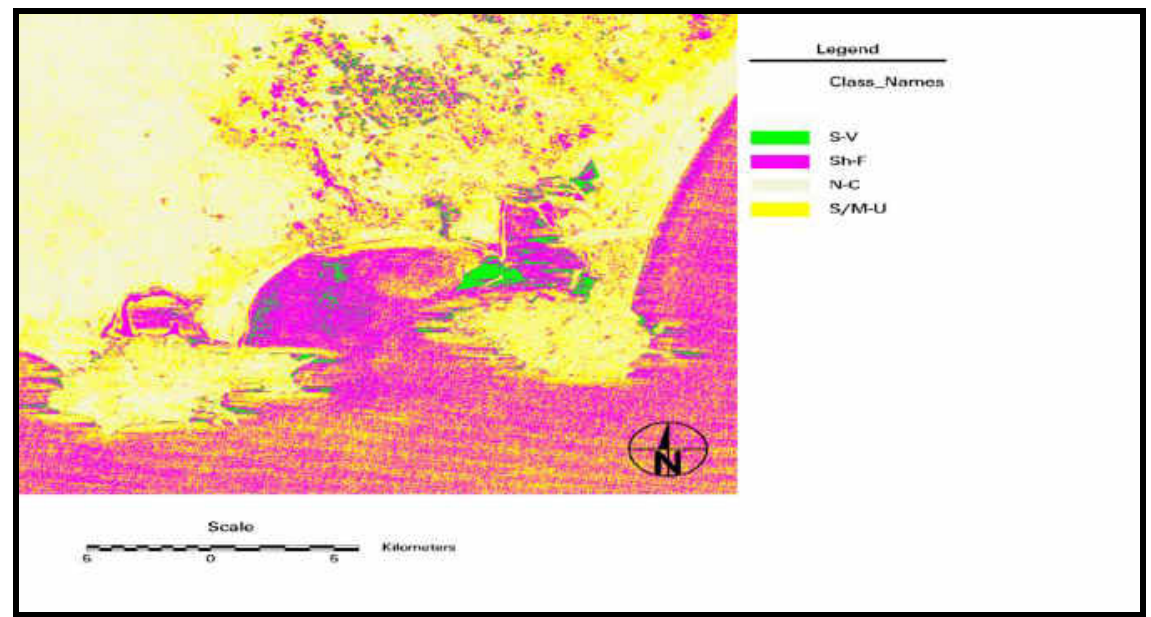

Plate 5: Classified image using NDVI difference image technique

Table 3: Error matrix of classified image using NDVI technique

\begin{tabular}{|c|c|c|c|c|c|c|c|}
\hline $\begin{array}{l}\text { Class- } \\
\text { names }\end{array}$ & $\mathrm{S}-\mathrm{V}$ & Sh-F & $\mathrm{N}-\mathrm{C}$ & $\mathrm{S} / \mathrm{M}-\mathrm{U}$ & Total & $\begin{array}{l}\text { Producer } \\
\text { accuracy }\end{array}$ & $\begin{array}{c}\text { Users } \\
\text { accuracy }\end{array}$ \\
\hline $\mathrm{S}-\mathrm{V}$ & 69 & 3 & 0 & 127 & 199 & $26.74 \%$ & $34.67 \%$ \\
\hline Sh-F & 120 & 34 & 0 & 41 & 195 & $87.17 \%$ & $17.43 \%$ \\
\hline $\mathrm{N}-\mathrm{C}$ & 10 & 0 & 1193 & 682 & 1885 & 95.82 & $63.28 \%$ \\
\hline $\mathrm{S} / \mathrm{M}-\mathrm{U}$ & 59 & 2 & 52 & 1616 & 1729 & $65.53 \%$ & $93.46 \%$ \\
\hline Total & 38 & 27 & 147 & 211 & 423 & & \\
\hline \multicolumn{2}{|c|}{ Kappa $=53.24 \%$} & \multicolumn{4}{|c|}{ Overall accuracy $=72.65 \%$} & & \\
\hline
\end{tabular}

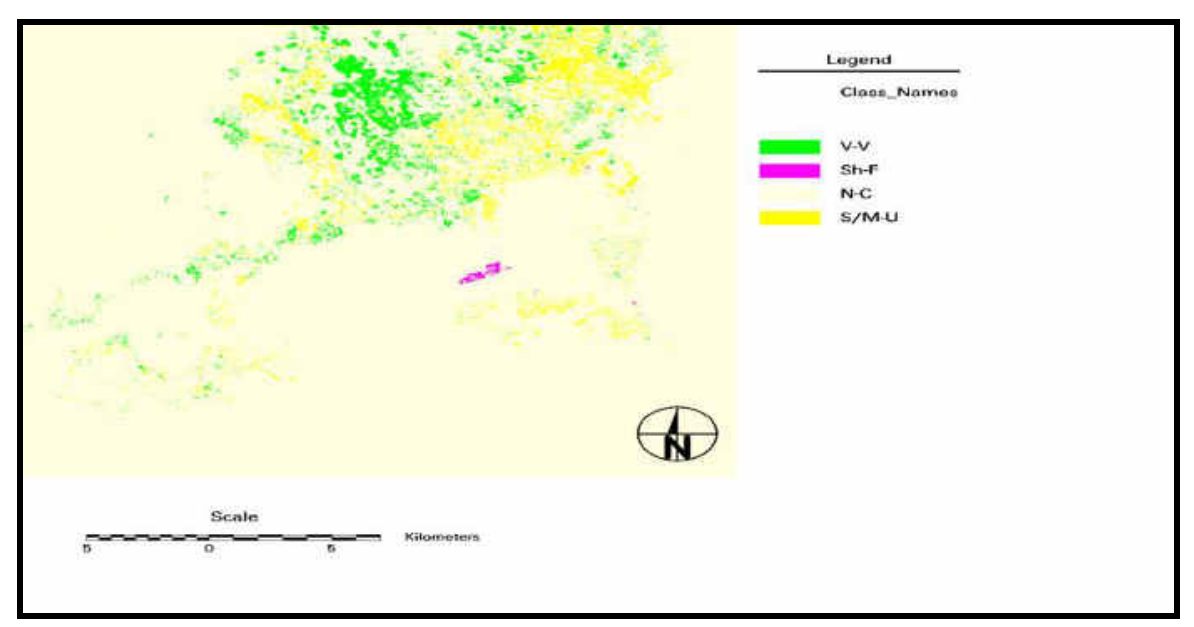

Plate 6: Classified image of compositing image 
Table 4: Error matrix of classified compositing image

\begin{tabular}{|c|c|c|c|c|c|c|c|}
\hline $\begin{array}{c}\text { Class- } \\
\text { names }\end{array}$ & S-V & Sh-F & N-C & S/M-U & Total & $\begin{array}{c}\text { Producer } \\
\text { accuracy }\end{array}$ & $\begin{array}{c}\text { Users } \\
\text { accuracy }\end{array}$ \\
\hline S-V & 53 & 0 & 0 & 0 & 53 & $100 \%$ & $100 \%$ \\
\hline Sh-F & 0 & 113 & 0 & 0 & 113 & $100 \%$ & $100 \%$ \\
\hline N-C & 0 & 0 & 231 & 0 & 231 & $100 \%$ & $100 \%$ \\
\hline S/M-U & 0 & 0 & 0 & 184 & 184 & $100 \%$ & $100 \%$ \\
\cline { 1 - 4 } Total & 53 & 113 & 231 & 184 & 581 & & \\
\cline { 1 - 3 } Kappa $=100 \%$ & \multicolumn{7}{|c|}{ Overall accuracy=100\% } \\
\hline
\end{tabular}

\section{GRAPHICAL REPRESENTATION FOR CHANGES IN THE MAIN CLASSES}

Changes in main classes of the study area such as in Sand/Mountain areas to built-up areas and changes in Shallow sea water to filling areas can be represented by graphical map as shown in figures 1 and 2 respectively. Graphical map for change in each class can be obtained by drawing and overlaying vector layers for the same class in both periods.

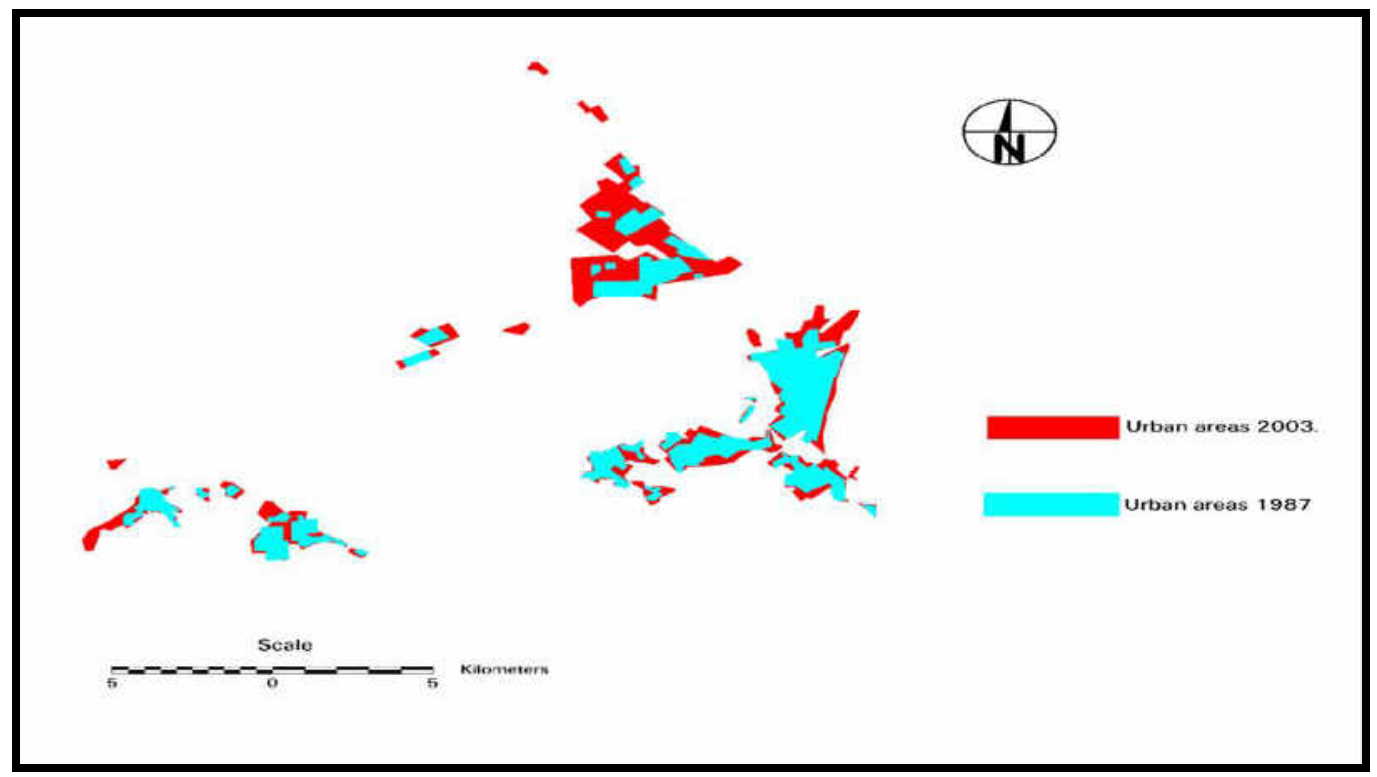

Fig. 1: Graphical map for urban areas changes between 1987 and 2003. 


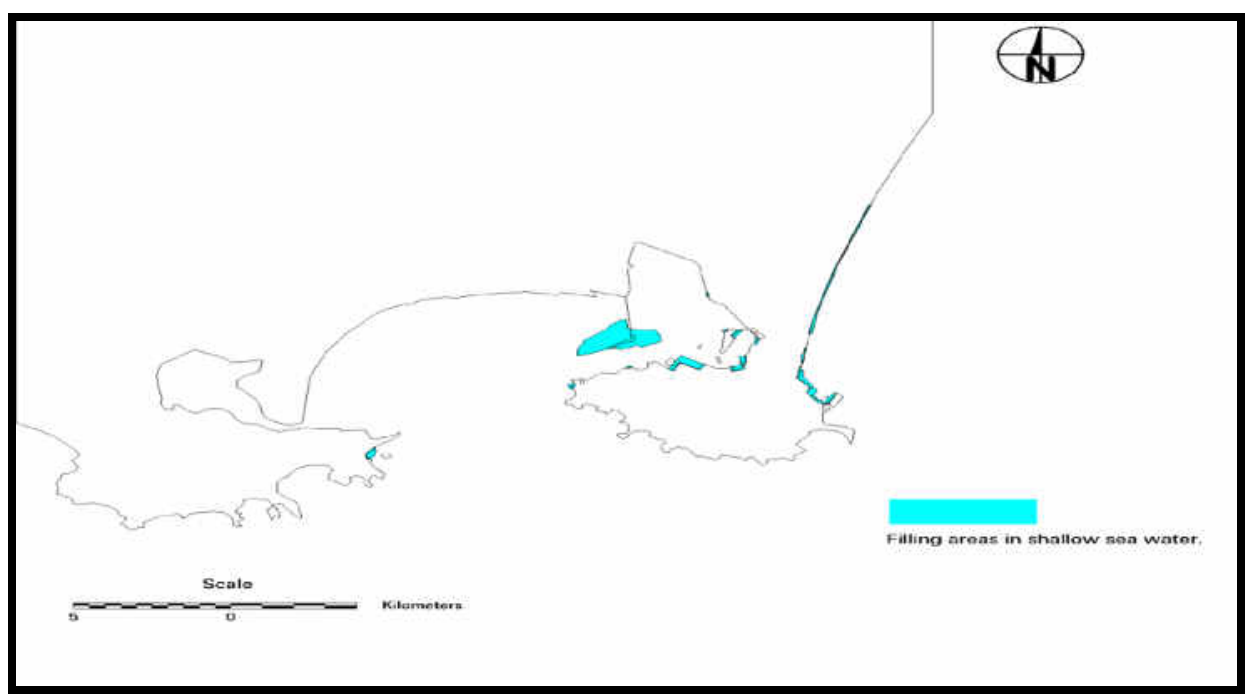

Fig. 2: Graphical map for filling areas in shallow sea water changes between 1987 and 2003.

\section{QUANTITATIVE ANALYSIS OF THE RESULTS}

Table 5 shows that the overall classification accuracy of different change detection techniques and producer's accuracy of change class are high in all methods except in the normalized differencing vegetation index which gives low accuracy. The sand to vegetation class has high accuracy in all techniques except in normalized differencing vegetation index technique has. Sand to urban class has high accuracy in all techniques except in normalized differencing vegetation index technique. Shallow sea water to soil filling class has high accuracy in all techniques. Sand/Mountain to urban class has a high accuracy in all techniques except in normalized differencing vegetation index technique.

In order to carry out the quantitative analysis of the changes in different classes, the resulting classified image from compositing image analysis (which gave the highest accuracy) was used in calculating areas of the different classes as shown in Table 6 .

\section{CONCLUSIONS}

This paper demonstrated the advantages of mostly used change detection techniques for detecting and mapping changes in Aden governorate (Republic of Yemen). High accuracy was obtained using compositing image, image differencing, and post classification comparison $(100 \%, 99.46 \%$, and $99.25 \%)$, respectively, it is found to be efficient technique for detecting and monitoring changes in land cover. Lowest accuracy was obtained by normalize difference vegetation index (72\%).

The highest percentage of change was found in class shallow sea water which changed to soil filling $(40.29 \%)$, the percentage of change in class sand/mountain which changed to urban (32.49\%), the percentage of change in class sand which changed to vegetation (18.20\%), and the percentage of no change class $(8.39 \%)$. 
Table 5: Overall accuracy of different change detection techniques and producer's accuracy of change classes

\begin{tabular}{|c|c|c|c|c|c|c|c|}
\hline \multirow{2}{*}{$\begin{array}{c}\text { Change } \\
\text { detection } \\
\text { method }\end{array}$} & \multirow{2}{*}{$\begin{array}{c}\text { Classification } \\
\text { method }\end{array}$} & Overall & Overall & \multicolumn{3}{|c|}{ Producer's accuracy \% } \\
\cline { 7 - 9 } & kappa & N-C & S-V & $\begin{array}{c}\text { S/M- } \\
\text { U }\end{array}$ & Sh-F \\
\hline $\begin{array}{c}\text { Post } \\
\text { classification } \\
\text { comparison }\end{array}$ & $\begin{array}{c}\text { Maximum } \\
\text { likelihood } \\
\text { classification }\end{array}$ & $99.25 \%$ & $98.60 \%$ & 100 & 100 & 98.66 & 94.79 \\
\hline $\begin{array}{c}\text { Image difference } \\
\text { All band }\end{array}$ & $\begin{array}{c}\text { Maximum } \\
\text { likelihood } \\
\text { classification }\end{array}$ & $99.46 \%$ & $98.81 \%$ & 99.55 & 100 & 99.21 & 100 \\
\hline $\begin{array}{c}\text { Normalized } \\
\text { differencing } \\
\text { vegetation index }\end{array}$ & $\begin{array}{c}\text { Maximum } \\
\text { likelihood } \\
\text { classification }\end{array}$ & $72 \%$ & $53.24 \%$ & 95.82 & 26.47 & 65.53 & 81.17 \\
\hline $\begin{array}{c}\text { Compositing } \\
\text { image }\end{array}$ & $\begin{array}{c}\text { Maximum } \\
\text { likelihood } \\
\text { classification }\end{array}$ & $100 \%$ & $100 \%$ & 100 & 100 & 100 & 100 \\
\hline
\end{tabular}

Table 6: Result of change classes that detected in period 1987-2003 in Aden governorate.

\begin{tabular}{|c|c|c|}
\hline Class & Area in hectare & Area in \% \\
\hline S-V & 16431.57 & 18.20 \\
\hline Sh-F & 37004.31 & 40.92 \\
\hline N-C & 7594.20 & 8.39 \\
\hline S/M-U & 29382.66 & 32.49 \\
\hline Total & 90412.74 & 100 \\
\hline
\end{tabular}

\section{REFERENCES}

1. Aldakheel Yuosef, Al-hussainai Abdurrahman, 2005. The Use of Multitemporal Landsat TM Imagery to Detect Landcover/ Landuse Changes in Al-Hassa, Saudi Arabia. Scientific Journal of King Faisal University (Basic and Applied Sciences), Vol.6, No.1, 2005.

2- Janzen, Darren T., Fredeen Arthur L., and Wheate Roger D., 2006. Radiometric correction techniques and accuracy assessment for Landsat TM data in remote forested regions. Journal of Remote Sensing vol. 32, No. 5, PP. 330340, 2006.

3- Jensen, J. R., 1996. Introductory Digital Image Processing. Prentice-Hall, Inc.

4- Lillesand, Thomas M., Ralph W. Keifer, 2000, Remote Sensing and Image Interpretation, John Wiley and Sons, Inc.

5- Peters Albert J., Elizabeth A. Walter-Shea, Lei Ji., Drought Monitoring with NDVI Based Standardized Vegetation Index. Photogrammetric Engineering and Remote Sensing, Vol. 68, No.1, 2002, PP. (71-75). 
6- Peterson Dana, Egbert Stephen, Auver, Chris, 2006, Identifying and Understanding Landuse/Land cover Change in Kansas. http://www.Kars.ku.edu.

7- Ramachandra T.V., Uttam Kumar Geographical Resources Decision Support System for Land-use/Land-cover Dynamics Analysis, Proceedings of the FOSS/GRASS Users Conference Bangkok, Thailand, 12-14 September 2004.

8- Schroeder, Todd A, Cohen, Warren B., Song, Conghe, Canty, Morton J., Yang, Zhiqiang, 2006. Radiometric Correction of Temporal Landast Data for Characterization of Early Successional Forest Patterns in Western Oregon. Remote Sensing of Environment Vol. 103, PP. 16-26, 2006.

9- Seto K.C., C.E.Woodcock, C.Song, X.Huang, J.Lu and R.K.Kaufmann, Monitoring Land use Change in the Pearl River Delta Using Landsat TM, International Journal of Remote Sensing, 2002, vol.23, No.10, pp 1985-2004.

10- Singh A.1989, Digital Change Detection Technique Using Remotely Sensed Data, International Journal of Remote Sensing, Vol.10, No.6, p989-1003.

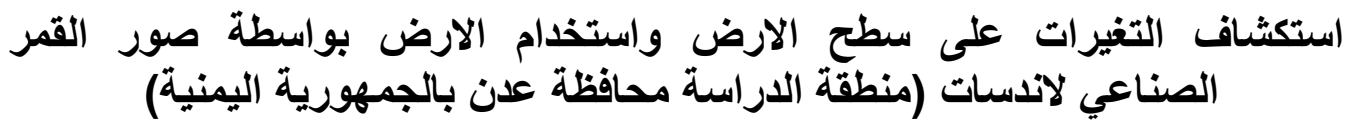

بإقامة وحدة شطري اليمن في عام •99 19 و إعلان محافظة عدن العاصمة الاقتصادية والتجارية, فقد أدى هذا إلى زيادة الهجرة إليها و ظهور الاستتمار بشكل كبير حيث حدث فيها تغيير بشكل ملحوظ.

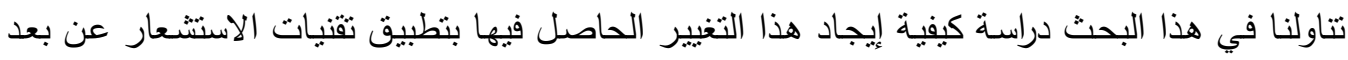
التي أثتتت دقتها العالية في إستكثاف التغييرات الناتجة على سطح الأرض في فترات زمنية مختلفة,

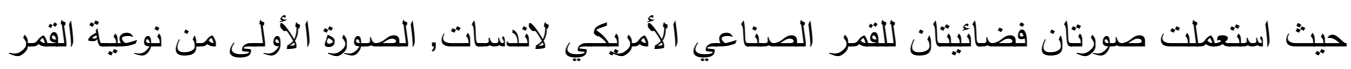

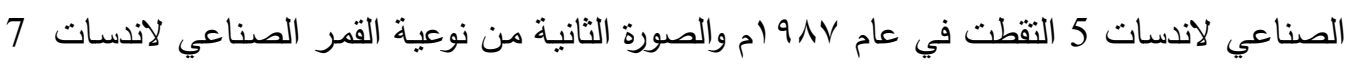

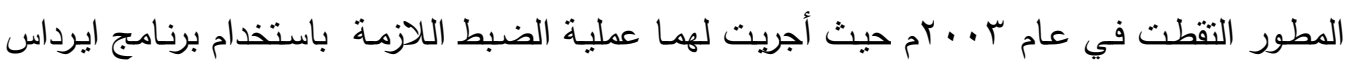

الطرق المستخدمة في نطبيق إاستكثاف التغيرات المختلفة على المنطقة كالتالي:

Post classification comparison, Image differencing, Compositing image, and Normalize differencing vegetation index.

أعلى كفاءة تم الحصـول عليها عن طريـق استخدام جميع الطـرق مـا عدا طريقة Normalize differencing vegetation index استتناج مساحة التغيرات الحادثة في منطقة الدراسة حيث تبين أن أكبر تغير حدث في ردم المساحات البحرية بنسبة.40.92\% من منطقة الدراسة في حين أن التغير من أراضٍ رملية وجبلية إلى سكنية كان 